\title{
Relationship between Smoking Activity and Chronic Obstructive Pulmonary Disease in the Zainoel Abidin General Hospital, Banda Aceh, Indonesia
}

\author{
Liza Salawati ${ }^{1 \star}$, Husnah Husnah ${ }^{2}$, Yusuf S. Nawawi ${ }^{1}$, Zainal A. Muchlisin ${ }^{3}$ \\ ${ }^{1}$ Department of Public Health, Faculty of Medicine, Syiah Kuala University, Banda Aceh, Indonesia; ${ }^{2}$ Department of Nutrition, \\ Faculty of Medicine, Syiah Kuala University, Banda Aceh, Indonesia; ${ }^{3}$ Department of Aquaculture, Faculty of Marine and \\ Fisheries, Syiah Kuala University, Banda Aceh, Indonesia
}

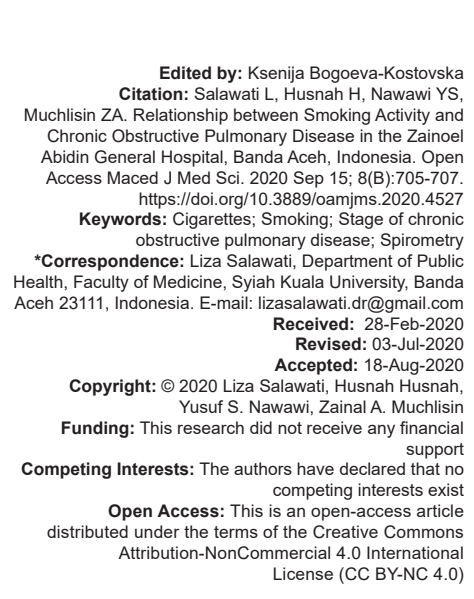

\section{Introduction}

Chronic obstructive pulmonary disease (COPD) is one of the major causes of morbidity and mortality worldwide [1], which leads to the death of individuals every $10 \mathrm{~s}$ around the world [2]. It is estimated that in 2013, COPD will be the third leading cause of death worldwide after heart disease and stroke [3]. Indonesia is one of the most vulnerable countries to COPD, and East Nusa Tenggara and Aceh Provinces have the highest prevalence of COPD in Indonesia [4].

According to the World Health Organization Report on the Global Tobacco Epidemic, Indonesia is one of the countries with the highest number of smokers in the world [5]. Cigarette smoke is presumed to be a major causative factor of COPD worldwide, including in Indonesia [6], [7]. Continuous and prolonged exposure to cigarette smoking causes disturbance in the airway mucosa, leading to respiratory disorders [8], [9]. Approximately $75 \%$ of cases of chronic bronchitis and emphysema are caused by cigarette smoke, and about $45 \%$ of smokers are at risk from COPD [3], [10]. COPD symptoms rarely manifest at a young age, with the symptoms commonly occurring in patients over 50 years of age, with the highest prevalence at 55-74 years [11]. This is because symptoms only appear in cases of continuous and long-lasting exposure to cigarette smoke [12]. At present, there is no information available concerning the relationship between smoking and COPD in Indonesia. Hence, the objective of the present study was to examine the relationship between smoking intensity and stage of CPOD in patients at the Zainoel Abidin General Hospital (ZAGH), Aceh Province, Indonesia.

\section{Methods}

This is an observational study with a crosssectional survey design. The study was conducted at the pulmonary ward of ZAGH, Banda Aceh, Indonesia, from September to November 2015. All the patients referred to the pulmonary ward with COPD were taken as the sample population. 


\section{Data collection}

The smoking intensity was divided into three categories based on the Brinkman and Coates Index [13], which measures the average number of cigarettes smoked per day multiplied by total days of smoking in a year. The categories are as follows: Low intensity, up to 200 cigarettes a year; moderate intensity, 200-600 cigarettes a year and heavy intensity, more than 600 cigarettes a year.

The stage of COPD was determined using a spirometer. The staging of COPD was based on criteria proposed by Global Initiative for Chronic Obstructive Lung Disease (GOLD) [1] as follows: Stage 0 (at risk) is having one or more symptoms of chronic cough, sputum production, and dyspnea, with documented exposure of risk factors and normal spirometry; Stage I (mild) is generally, but not always, chronic cough and sputum production, with spirometry results of forced expiratory volume in 1 s/forced vital capacity (FEV1/FVC) $<70 \%$, FEV1 $\geq 80 \%$; Stage II (moderate) symptoms of shortness of breath, which develop on exertion, with spirometry results of FEV1/FVC <70\%, 50\% <FEV1 <80\%; Stage III (severe) has the progressive symptoms of shortness of breath, reduced exercise capacity, and repeated exacerbations, with spirometry results of FEV1/FVC $<70 \%, 30 \%<\mathrm{FEV} 1<50 \%$; and Stage IV (very severe) has a respiratory failure with the sign of right heart failure, with spirometry result of FEV1/FVC $<70 \%$, FEV1 $<30 \%$ or $<50 \%$. Data were subjected to the KolmogorovSmirnov test at the significance level $(\alpha)=0.05$.

\section{Results}

A total of 60 male patients were involved in the study. The patients were all diagnosed with COPD. The age range of patients was between 40 and 72 years, and the occupations were predominantly farmers and construction workers. Most of the patients were heavy smokers (Table 1). The results showed that $50 \%$ of mild smokers had Stage I COPD; most of the moderate smokers had Stage III COPD; and most of the heavy smokers had Stage III and IV COPD (Table 2). The Kolmogorov-Smirnov test showed $p=0.007$, indicating

Table 1: Characteristics of patients with chronic obstructive pulmonary disease in the pulmonary ward in Zainoel Abidin General Hospital, Banda Aceh, Indonesia

\begin{tabular}{lll}
\hline Characteristics of respondents & $\mathrm{N}$ & $\%$ \\
\hline Age, years & 33 & \\
$\quad 40-60$ & 27 & 55.00 \\
$\quad>60$ & & 45.00 \\
Occupation & 35 & 58.33 \\
Farmer & 6 & 10.00 \\
Trader & 10 & 16.67 \\
Construction worker & 3 & 5.00 \\
Factory worker & 4 & 6.67 \\
$\quad$ Government employee & 2 & 3.33 \\
$\quad$ Retired & & \\
Smoking intensity & 6 & 10.00 \\
$\quad$ Mild & 16 & 26.67 \\
Moderate & 38 & 63.33 \\
Heavy & & \\
\hline
\end{tabular}

that there is a strong relationship between smoking intensity and COPD stage among patients with COPD.

Table 2: Smoking relationship with the stage of COPD

\begin{tabular}{|c|c|c|c|c|c|c|c|c|c|c|c|}
\hline \multirow{3}{*}{$\begin{array}{l}\text { Smoking } \\
\text { intensity }\end{array}$} & \multicolumn{8}{|c|}{ COPD stage $^{*}$} & \multirow{2}{*}{\multicolumn{2}{|c|}{ Total }} & \multirow[t]{3}{*}{$p$-value } \\
\hline & \multicolumn{2}{|l|}{$\mathrm{I}$} & \multicolumn{2}{|l|}{ II } & \multicolumn{2}{|l|}{ III } & \multicolumn{2}{|l|}{ IV } & & & \\
\hline & $\mathrm{n}$ & $\%$ & $n$ & $\%$ & $n$ & $\%$ & $n$ & $\%$ & $\mathrm{n}$ & $\%$ & \\
\hline Low & 3 & 50.00 & 2 & 33.33 & 1 & 16.67 & 0 & 0 & 6 & 100 & 0.007 \\
\hline Moderate & 1 & 6.25 & 5 & 31.25 & 8 & 50.00 & 2 & 12.50 & 16 & 100 & \\
\hline Heavy & 1 & 2.63 & 11 & 28.95 & 13 & 34.21 & 13 & 34.21 & 38 & 100 & \\
\hline Total & 5 & & 18 & & 22 & & 15 & & 60 & & \\
\hline
\end{tabular}

\section{Discussion}

Our study demonstrated that most of the COPD patients were heavy smokers, which are similar to results reported by other researchers in Adam Malik General Hospital (Medan) and M. Djamil Hospital (Padang), Indonesia [14], [15]. Most of the patients had Stage III COPD, and these patients had deteriorated clinically and were being treated in intensive care in the hospital. This is in agreement with the GOLD criteria, where COPD patients in Stage II begin to show deterioration in the flow resistance of the air, accompanied by shortness of breath. At this stage, these patients begin to seek treatment due to the shortness of breath that they felt. COPD patients at Stage III experience more severe shortness of breath, decreased exercise capacity, and repeated exacerbations, which may have an impact on the quality of life of patients. Therefore, most patients need to be hospitalized [1]. The relationship between smoking and COPD is a dose-response relationship, where the risk of COPD is increased as an increasing number of cigarettes are smoked per day and the longer the smoking habit [16], [17]. Samples of bronchoalveolar fluid from COPD smokers showed that smoking greatly contributes to morbidity and mortality, and there is an increase in the number of macrophages and neutrophils in smokers than non-smokers [18], [19]. Respiratory symptoms, such as coughing, mucus hypersecretion, and respiratory tract obstruction, are more prevalent among active smokers. They are also at a high risk of COPD depending on the number of cigarettes smoked per day, age of starting smoking, and how long the person has smoked [16].

In Indonesia, $70 \%$ of deaths due to chronic lung disease and emphysema are due to tobacco use, and half a million people in Indonesia suffer from respiratory diseases caused by tobacco use [17]. This is due to irritative and toxic substances contained in cigarettes, such as nicotine, carbon monoxide, and tar. Nicotine has negative effects on health for several reasons. It may cause constriction of the pulmonary terminal bronchioles, which increases resistance to airflow into and out of the lungs and can paralyze ciliary systems on the surface of respiratory epithelial cells, which normally move constantly to remove excess fluid and foreign particles from the airways, resulting in debris accumulation in the airways. The irritating effect of cigarette smoke causes 
increased secretion of fluid into the branches of the bronchi, as well as swelling of the epithelial layer [20].

\section{Conclusions}

COPD patients in the pulmonary ward of ZAGH are mostly heavy smokers, and most of these patients have Stage III COPD (severe). There is a strong relationship between smoking intensity and the stage of COPD in patients with COPD in the pulmonary ward of ZAGH, Banda Aceh.

\section{Ethical Statement}

The study was conducted in compliance with the Syiah Kuala University Research Ethics Guidelines and approved by the Medical Ethics Commission of the Medical Faculty, Syiah Kuala University (Ethics Code No. 958/2015).

\section{Informed Consent}

The patients were consulted and agreed to participate in the study and informed consent was obtained from the patient.

\section{Acknowledgments}

The authors would like to thank the colleagues in the ZAGH, Banda Aceh who helped during data collection and analysis.

\section{References}

1. The Global Initiative for Chronic Obstructive Lung Disease (GOLD). Global Strategy for the Diagnosis, Management and Prevention of COPD; 2016. Available from: http://www. goldcopd.org. [Last accessed on 2016 May 16].

2. Tan WC, Ng TP. COPD in Asia where East meets West. Chest. 2008;133(2):517-27.

PMid: 18252918

3. Eriksen M, Mackay J, Ross H. The Tobacco Atlas. Atlanta, GA American Cancer Society. New York: World Lung Foundation; 2015. Available from: http://www.tobaccoatlas.org. [Last accessed on 2016 May 16]. https://doi.org/10.1002/wmh3.49

4. Indonesia Ministry of Health. Riset Kesehatan Dasar. National
Institute of Health Research and Development. Jakarta: Indonesia Ministry of Health; 2013. https://doi.org/10.25133/jpssv27n1.003

5. World Health Organization. Report on the Global Tobacco Epidemic; 2015. Available from: http://www.who.int/tobacco/surveillance/ policy/country_profile/idn.pdf. [Last accessed on 2016 May 16].

6. Laniado-Laborín, R. Smoking and chronic obstructive pulmonary disease (COPD). Parallel epidemics of the $21^{\text {st }}$ century. Int J Environ Res Public Health. 2009;6(1):209-24. https://doi. org/10.3390/ijerph6010209

PMid: 19440278

7. Persatuan Dokter Paru Indonesia. Penyakit Paru Obstruktif Kronik: Pedoman Diagnosis dan Penatalaksanaan di Indonesia; 2011. Available from: http://www.klikpdpi.com/konsensus/ konsensus-ppok/ppok.pdf. [Last accessed on 2016 Dec 31]. https://doi.org/10.26891/jik.v10i2.2016.71-79

8. Prasenohadi. PPOK dan Tuberkulosis. J Respirol Indones. 2007;27(3):141-2.

9. Nici L, ZuWallack R. American Thoracic Society Subcommittee on Integrated Care of the COPD Patient. An official american thoracic society workshop report: The integrated care of the COPD patient. Proc Am Thorac Soc 2012;9(1):9-18. https://doi. org/10.1513/pats.201201-014st

10. World Health Organization. Chronic Obstructive Pulmonary Disease. Geneva: World Health Organization; 2016. Available from: http://www.who.int/tobacco/research/copd/en. [Last accessed on 2016 Mar 06].

11. Barus AP, Nusdwinuringtyas N, Ratnawati A, Widyahening IS. The effect of electrical stimulation on strength of quadriceps femoris muscles in acute exacerbation and post acute exacerbation COPD patients. Majalah Kedokteran Indones. 2010;60(6):273-8.

12. Van Durme $Y M$, Verhamme KM, Stijnen T, van Rooij FJ, Van Pottelberge GR, Hofman A, et al. Prevalence, incidence, and lifetime risk for the development of COPD in the elderly: The Rotterdam study. Chest. 2009;135(2):368-77. https://doi. org/10.1378/chest.08-0684

13. Brinkman GL, Coates EO Jr. The effect of bronchitis, smoking and occupation on ventilation. Am Rev Respir Dis. 1963;87:684-93.

14. Nisa K. Prevalensi Penderita Penyakit Paru Obstruksi Kronik Dengan Riwayat Merokok di Rumah Sakit Umum Pusat Haji Adam Malik Medan priode Januari 2009-Desember 2009. Medan: Universitas Sumatera Utara; 2010. https://doi. org/10.15851/jap.v4n2.819

15. Anwar D, Chan Y, Basyar M. Hubungan derajat sesak napas penderita penyakit paru obstruktif kronik menurut kuesioner modified medical research council scale dengan derajat penyakit paru obstruktif kronik. J Respirol Indones. 2012;32(4):200-7. https://doi.org/10.33024/hjk.v13i4.1670

16. Liu $Y$, Pleasants RA, Croft JB, Wheaton AG, Heidari $K$ Malarcher AM, et al. Smoking duration, respiratory symptoms, and COPD in adults aged $\geq 45$ years with a smoking history. Int J Chron Obstruct Pulmon Dis. 2015;10:1409-16. https://doi. org/10.2147/copd.s82259 PMid:26229460

17. Indonesian Ministry of Health. Pedoman Pengendalian Penyakit Paru Obstruktif Kronik. Jakarta: Depkes Republic of Indonesia; 2008.

18. Rima A, Suradi, Surjanto E, Yunus F. Korelasi antara jumlah makrofag, neutrofil dan kadar enzim matrix metalloproteinase pada cairan kurasan bronkial perokok. J Respirol Indones. 2007;27(3):143-4.

19. Lee J, Taneja V, Vassallo R. Cigarette smoking and inflammation: Cellular and molecular mechanisms. J Dent Res. 2012;91(2):142-9. https://doi.org/10.1177/0022034511421200 PMid:21876032

20. Guyton AC, Hall JE. Effect of smoking on pulmonary ventilation in exercise. In: Textbook of Medical Physiology. $11^{\text {th }}$ ed. United States: Elsevier Saunders; 2006. p. 1062. 